\title{
Orchidaceae na Reserva do Poço Escuro, Vitória da Conquista, Bahia, Brasil
}

\author{
Lucas Cardoso Marinho ${ }^{1,2^{*}}$ \& Cecília Oliveira de Azevedo ${ }^{1}$ \\ ${ }^{1}$ Programa de Pós-Graduação em Botânica, Departamento de Ciências Biológicas, Universidade Estadual de Feira \\ de Santana, Feira de Santana, Bahia, Brasil. \\ ${ }^{2}$ Departamento de Ciências Naturais, Universidade Estadual do Sudoeste da Bahia, Vitória da Conquista, Bahia, \\ Brasil.
}

\begin{abstract}
Resumo - O presente estudo trata do levantamento florístico das Orchidaceae ocorrentes na Reserva do Poço Escuro, município de Vitória da Conquista, Bahia, Brasil, realizado através de levantamento bibliográfico, excursões mensais à área estudada e análise do material dos principais herbários baianos. O trabalho apresenta chave de identificação, descrição, ilustração, comentários sobre a morfologia, hábito, aspectos fenológicos e distribuição geográfica de 12 espécies da família Orchidaceae, contribuindo ao conhecimento da família no estado da Bahia.

Palavras-chave adicionais: florística, orquídeas, sudoeste baiano.
\end{abstract}

\begin{abstract}
Orchidaceae from the Poço Escuro Reserve, Vitória da Conquista, Bahia, Brazil) - The present study deals with a floristic survey of the Orchidaceae occurring in the Poço Escuro reserve, municipality of Vitória da Conquista, Bahia, Brazil, which was conducted through a literature review, monthly field trips to the area studied and analysis of the materials of the main herbaria in Bahia. This work presents an identification key, descriptions, illustrations, comments on the morphology, habit, phenology and geographical distribution of the 12 species of Orchidaceae occurring in the Reserve, thus contributing to the knowledge of the family in the state of Bahia.
\end{abstract}

Additional key words: floristics, orchids, southwestern Bahia.

Orchidaceae possui ampla representatividade no Brasil, com aproximadamente 230 gêneros e 2.400 espécies (Pabst \& Dungs 1975, 1977; Barros et al. 2012). Estudos florísticos na Bahia indicam que aproximadamente 420 espécies de orquídeas ocorrem no Estado (Harley \& Simmons 1986; Toscano-de-Brito 1995, 1998; Toscano-de-Brito \& Queiroz 2003; Toscano-de-Brito \& Cribb 2005; van den Berg \& Azevedo 2005; Azevedo \& van den Berg 2007). No entanto, esses trabalhos privilegiaram essencialmente as áreas de campos rupestres, possivelmente, devido ao grande número de espécies e endemismo nestes locais (Gentry 1992; Giulietti et al. 2000); formações florestais, como as áreas de transição, conhecidas como florestas estacionais semideciduais, ainda são pouco estudadas no Estado.

Com o intuito de ampliar o conhecimento acerca da flora da Bahia, este trabalho objetivou inventariar, descrever e ilustrar as espécies de Orchidaceae presentes na Reserva do Poço Escuro, no sudoeste do Estado. Levantamentos nestas áreas (Marinho \& Azevedo 2011; Azevedo \& Marinho 2012) registraram novas ocorrências para o Nordeste, demonstrando a importância de trabalhos florísticos na região. Todavia, este é o primeiro levantamento florístico da família no sudoeste da Bahia.

\section{MATERIAIS E MÉTODOS}

A Reserva do Poço Escuro (coordenada central:

\footnotetext{
*Autor para correspondência: 1cmarinho1@gmail.com

Editor responsável: Julio Lombardi

Submetido: 16 ago. 2012; aceito: 17 mar. 2013

Publicação inicial: 26 jul. 2013; versão final: 2 maio 2014
}

$\left.14^{\circ} 50^{\prime} \mathrm{S}, 40^{\circ} 50^{\prime} \mathrm{W}\right)$ faz parte do Parque Municipal da Serra do Periperi, Vitória da Conquista, Bahia, Brasil, estando a aproximadamente $1.000 \mathrm{~m}$ de altitude. Possui aproximadamente 17 ha e constitui um dos últimos remanescentes florestais da zona urbana da cidade (Soares-Filho 2000). A vegetação predominante é classificada como floresta estacional semidecidual, resultado de gradiente de umidade mais elevado devido à sua localização no planalto da Conquista (Queiroz et al. 2006). O Poço Escuro possui uma área mais elevada em relação ao nível do mar, com uma vegetação mais seca, composta por árvores de pequeno porte e lianas lenhosas, e outra área mais úmida, ao sul da serra, com árvores de maior porte, dentro do conceito já levantado por Veloso et al. (1991), que caracteriza a floresta semidecídua como sendo heterogênea, com variações de substrato, fatores climáticos e topografia.

O trabalho foi realizado entre maio de 2010 e agosto de 2011, com excursões mensais à área. O material coletado foi herborizado segundo Mori et al. (1989) e depositado no herbário da Universidade Estadual do Sudoeste da Bahia campus de Vitória da Conquista (HUESBVC). Além de levantamento bibliográfico, foram consultados os acervos dos herbários baianos ALCB, CEPEC, HRB, HUEFS, HUESBVC (siglas de acordo com Thiers 2012). As descrições incluem medidas de materiais examinados de locais próximos à área de estudo e os comentários sobre a fenologia das espécies estão baseados em observações de campo.

\section{RESUltados}

Foram encontradas 12 espécies de Orchidaceae, distribuídas em 12 gêneros. Resultados mais 
expressivos em número de espécies foram obtidos em trabalhos realizados em outros fragmentos de floresta estacional semidecídual: Menini Neto et al. (2007a) e Pansarin \& Pansarin (2008) levantaram cerca de 120 espécies em áreas superiores à 1.000 ha.

Para a floresta semidecidual da área da Reserva Biológica da Represa Gama, Menini Neto et al. (2004) citaram 28 espécies distribuídas em 268 ha, sendo este um resultado mais próximo do encontrado na Reserva do Poço Escuro, possivelmente devido a diversas intervenções antrópicas que ocorrem em ambas as áreas. A Reserva do Poço Escuro possui menor extensão e encontra-se localizada em área urbana densamente povoada, estando sujeita, desde o início da formação da cidade, à interferência antrópica.

\section{DISCUSSÃo}

Aproximadamente $60 \%$ das espécies ocorrentes na Reserva Poço Escuro (Acianthera saurocephala,
Campylocentrum micranthum, Oeceoclades maculata, Polystachya estrellensis, Prescottia stachyodes, Psilochilus modestus e Trichocentrum pumilum) também ocorrem na floresta semidecídua da Serra do Japi, estado de São Paulo (Pansarin \& Pansarin 2008). Das espécies coletadas no Poço Escuro, apenas Prescottia stachyodes está presente em todas as áreas dos trabalhos mencionados (Menini Neto et al. 2004, 2007a; Pansarin \& Pansarin 2008). Além disto, com exceção de Acianthera saurocephala e Psilochilus modestus, cerca de $83 \%$ das espécies amostradas na área de estudo também ocorrem em áreas de campo rupestre (Harley \& Simmons 1986; Toscano-de-Brito 1995, 1998; Toscano-de-Brito \& Queiroz 2003; Toscano-de-Brito \& Cribb 2005; van den Berg \& Azevedo 2005; Azevedo \& van den Berg 2007), demonstrando que as espécies aqui citadas possuem ampla distribuição no estado da Bahia e toleram diferentes tipos de ambientes.

\section{Tratamento TAXONÔMICO}

\section{Chave de identificação}

1. Inflorescência lateral.

2. Caule não espessado em pseudobulbo; inflorescência em racemo; flores calcaradas

\section{Campylocentrum micranthum}

2'. Caule espessado em pseudobulbo; inflorescência em panícula; flores não calcaradas.

3. Pseudobulbo 1,5-5,5 cm compr., com folhas laterais; sépalas laterais conadas; calo central verrucoso ......

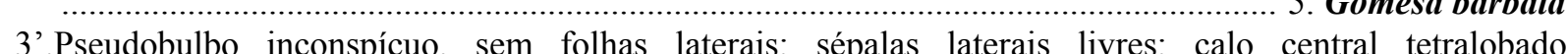
12. Trichocentrum pumilum

1'. Inflorescência terminal.

4. Ramicaule unifoliado.

5. Ramicaule inconspícuo; inflorescência com flor única; polínias 4

2. Barbosella crassifolia

5'. Ramicaule 1,5-18 cm compr.; inflorescência com mais de uma flor; polínias 2.

6. Folhas oblongas; flores vináceas, pilosas; sépalas laterais conadas ......... 1. Acianthera saurocephala 6'. Folhas lanceoladas a lineares; flores amarelo-esverdeadas, glabras; sépalas livres ..... 11.Stelis aprica

4'. Caule multifoliado.

7. Caule espessado em pseudobulbo.

8. Erva terrícola; folhas maculadas; flores calcaradas 6. Oeceoclades maculata

8'. Erva epífita; folhas não maculadas; flores não calcaradas 7. Polystachya estrellensis

7'. Caule não espessado em pseudobulbo.

9. Folhas ao longo do caule, dísticas, com face abaxial vinácea

9. Psilochilus modestus

9'. Folhas basais, dispostas em roseta, com face abaxial verde.

10. Flores não-ressupinadas; sépalas e pétalas revolutas; labelo cuculado; polínias 4

10'. Flores ressupinadas; sépalas e pétalas não revolutas; labelo trilobado; polínias 2.

11. Planta com folhas durante a floração; flores calcaradas, glabras ...... 4. Eltroplectris triloba 11'. Planta afila durante a floração; flores não calcaradas, pilosas . . 10. Sarcoglottis curvisepala

1. Acianthera saurocephala (Lodd.) Pridgeon \& M.W.Chase, Lindleyana 16(4): 246. 2001. Pleurothallis saurocephala Lodd., Bot. Cab. 16: t. 1571. 1829.

Figura 6A.
Erva epífita. Ramicaule 9,5-18 cm compr., ereto, unifoliado, verde, cilíndrico. Folhas 6,5-12 × 2,5-4 $\mathrm{cm}$, verdes, sésseis, carnosas, oblongas, ápice obtuso, base obtusa. Racemo terminal, pendente; pedúnculo 3,5-6,5 cm compr.; raque 6-12 cm compr.; brácteas 
florais 2-3,5 × 4-5 mm. Flores ressupinadas; pedicelo (incluindo ovário) 3-4 mm compr. Sépalas vináceas, carnosas, com três nervuras longitudinais, oblongas, ápice obtuso, base truncada, internamente verrucosa, externamente pilosa; sépala dorsal 7-9 × 3-4 $\mathrm{mm}$, conata na base às sépalas laterais; sépalas laterais 7-9 $\times 2-3 \mathrm{~mm}$, conatas até $2 / 3$ do comprimento. Pétalas 1,4-1,6 × 1-1,4 mm, esverdeadas, com uma nervura longitudinal, deltoides, membranáceas, ápice agudo, base atenuada. Labelo $2-3 \times 1-1,2 \mathrm{~mm}$, unido ao pé da coluna, vináceo, carnoso, trilobado, base atenuada, glabro; calosidade formando duas quilhas eretas na porção mediana do lobo terminal; lobo terminal, ovado, ápice obtuso; lobos laterais eretos, oblongos, ápice obtuso. Coluna 1,3-1,5 $\mathrm{mm}$ compr., alada próximo ao ápice; antera 0,3-0,5 $\mathrm{mm}$ compr., vinácea; polínias 2, triangulares a ovadas.

Material examinado - 26 set. 2010, L.C. Marinho et al. 4 (HUESBVC); 29 maio 2010, A.F.P. Machado \& A.K.A. Santos 963 (HUEFS).

Acianthera saurocephala foi descrita originalmente para o estado do Rio de Janeiro (Loddiges 1829) e citada apenas para os estados das Regiões Sul e Sudeste (Giongo \& Waechter 2004; Pansarin \& Pansarin 2008; Gonçalves \& Waechter 2011; Barros et al. 2012), sendo, recentemente, citada também para a Bahia (Marinho \& Azevedo 2011). É caracterizada por flores externamente pilosas e de interior verrucoso, podendo ser diferenciada das outras epífitas da área pela presença de um longo ramicaule e folhas oblongas (veja ilustração em Marinho \& Azevedo 2011). Ocorre em árvores de grande porte e floresce nos meses de junho e setembro.

2. Barbosella crassifolia (Edwall) Schltr., Repert. Spec. Nov. Regni Veg. 15: 261. 1918. Restrepia crassifolia Edwall, Revista Centro Sci. Campinas 2: 193. 1903.

Figuras $1 \mathrm{~A}-\mathrm{F}$ e $6 \mathrm{~B}-\mathrm{C}$.

Erva epífita. Ramicaule inconspícuo. Folhas 3,3-5,3 × 3-4,2 mm, verdes, coriáceas, ovadas, ápice obtuso, base retusa. Inflorescência uniflora, terminal, ereta ou levemente curva, 2,5-3,8 cm compr. Flores ressupinadas, esverdeadas com máculas vináceas, glabras. Sépalas esverdeadas, com três nervuras longitudinais vináceas, membranáceas, ápice agudo, base truncada, margem inteira; sépala dorsal 5,9-6,8 $\times$ 1,1-1,4 mm, lanceolada; sépalas laterais $5,1-5,5 \times$ 3-2,5 mm, ovadas, conatas. Pétalas 4,5-6 × 0,3-0,4 mm, com uma nervura longitudinal vinácea, lanceoladas a lineares, membranáceas, ápice agudo, base truncada, margem inteira. Labelo 2,2-3,3 mm compr., unido ao pé da coluna, esverdeado, com mácula vinácea, trilobado, base atenuada, margem inteira; lobo terminal ereto, ovado, ápice obtuso; lobos laterais elevados, oblongos, ápice obtuso. Coluna 1,5-2 mm compr., alada próximo ao ápice; antera $0,5-0,6 \mathrm{~mm}$ compr., amarela; polínias 4 , obovadas.
Material examinado - 1 jul. 2010, L.C. Marinho et al. 65 (HUESBVC).

Barbosella crassifolia ocorre nos estados de São Paulo, Minas Gerais, Santa Catarina, Rio Grande do Sul (Pabst \& Dungs 1975; Buzzato et al. 2008). Na Bahia, a espécie havia sido registrada apenas para o Pico das Almas, na Chapada Diamantina (Toscano-deBrito 1995; Toscano-de-Brito \& Cribb 2005). Dentre as espécies de Barbosella, diferencia-se pelas sépalas laterais largas e lobos laterais do labelo bem desenvolvidos (Pabst \& Dungs 1975). Diferencia-se das demais epífitas da Reserva pela inflorescência uniflora e pela presença de quatro polínias. Floresce em julho e foi coletada no interior da mata, em árvores de grande porte, com cerca de 20 a $30 \mathrm{~m}$ de altura.

3. Campylocentrum micranthum (Lindl.) Rolfe, Orchid Rev. 11: 245. 1903. Angraecum micranthum Lindl., Edwards's Bot. Reg. 21: t. 1772. 1835.

Figuras $1 \mathrm{G}-\mathrm{K}$ e $6 \mathrm{D}$.

Erva epífita. Rizoma inconspícuo. Caule 4,5-19 cm compr., multifoliado, verde, escandente, cilíndrico. Folhas 3,2-6 × 0,7-1,2 cm, verdes, sésseis, carnosas, oblongas, ápice retuso, base atenuada. Racemo lateral, $2-3,5 \mathrm{~cm}$ compr. Flores creme com extremidades alaranjadas, pedicelo (incluindo ovário) 2-3 $\mathrm{mm}$ compr., ressupinadas, calcaradas, glabras. Sépalas membranáceas, oblongas, ápice agudo, base truncada, margem inteira; sépala dorsal 1-1,1 $\times 2-3 \mathrm{~mm}$; sépalas laterais $1-1.5 \times 3-4 \mathrm{~mm}$. Pétalas $0,8-1 \times 2-3 \mathrm{~mm}$, membranáceas, oblongas, ápice agudo, base truncada, margem inteira. Labelo creme, base atenuada, membranáceo, ovado, trilobado; lobo terminal 1-1,2 $\times$ 1,5-1,7 mm, ápice agudo; lobos laterais inconspícuos, ápice obtuso. Coluna 1,25 mm compr.; antera 0,3-0,4 $\mathrm{mm}$ compr., alva; polínias 2, ca. 0,2 mm compr., orbiculares. Calcar 3-3,5 mm, alaranjado, cilíndricoarredondado.

Material examinado - 6 fev. 2011, L.C. Marinho \& C.O. Azevedo 15 (HUESBVC).

Campylocentrum micranthum possui ampla distribuição, ocorrendo desde o México até o sul do Brasil (Romero-González 2003), sendo, neste último, citada para todos os estados das Regiões Norte e Sudeste, além do Mato Grosso, Maranhão, Pernambuco e Bahia (Barros et al. 2012). Na Bahia, as coletas restringiam-se apenas à região da Chapada Diamantina, nos municípios de Mucugê, Palmeiras e Rio de Contas (Toscano-de-Brito \& Cribb 2005; Azevedo \& van den Berg 2007). A espécie pode ser diferenciada das demais na área estudada pelo crescimento monopodial, inflorescências laterais curtas e pela presença de calcar bem desenvolvido. Bem distribuída na Reserva, apresenta maior ocorrência na porção mais seca, podendo ser encontrada sobre arbustos e lianas. Floresce entre janeiro e junho. 


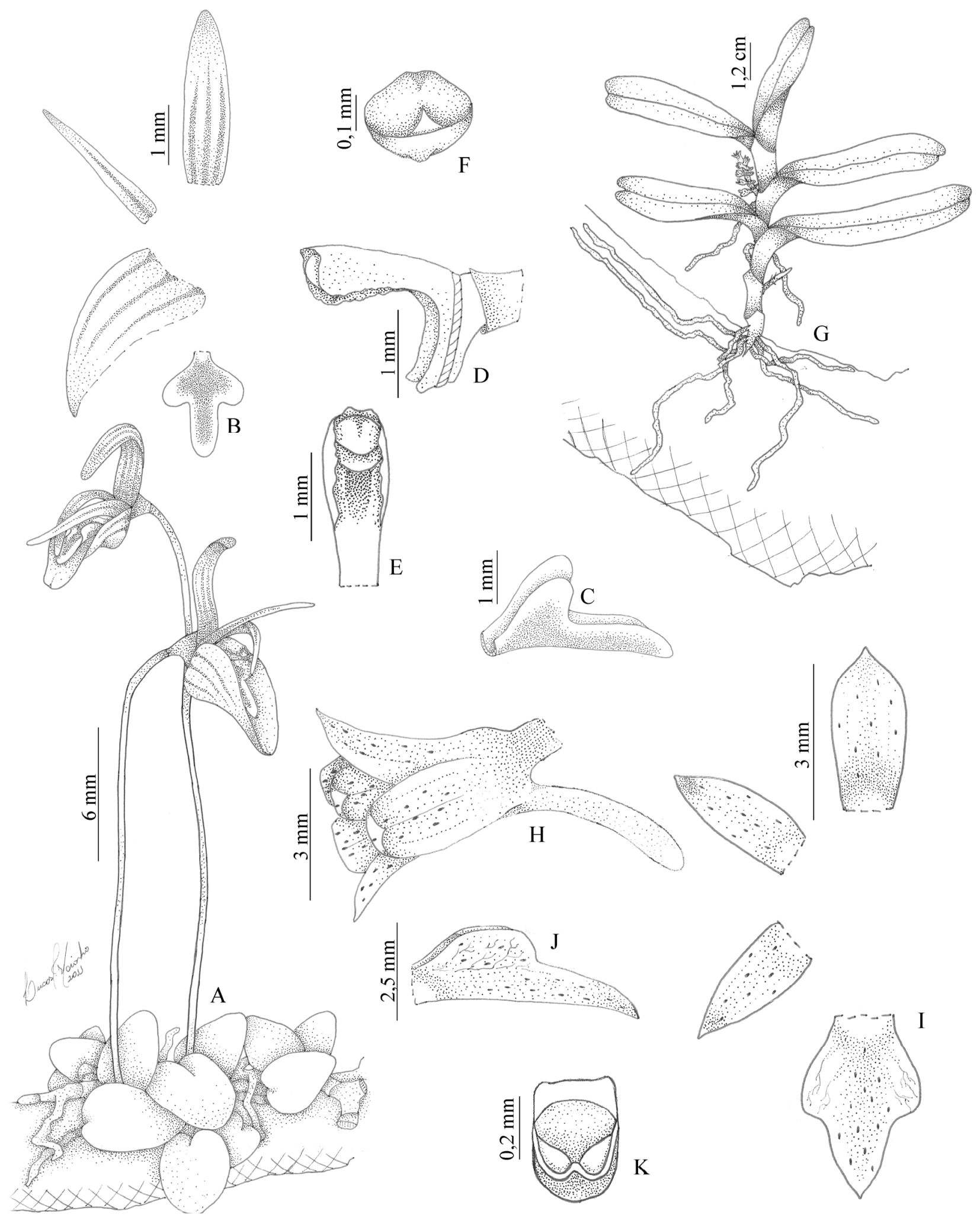

Figura 1. A-F. Barbosella crassifolia: A- hábito; B- perianto; C- Labelo, vista lateral; D- coluna, vista lateral; E- coluna, vista frontal; F- antera. G-K. Campylocentrum micranthum: G- hábito; H- flor; I- perianto; J- labelo, vista lateral; K- antera.

4. Eltroplectris triloba (Lindl.) Pabst, Bradea 1: 470. 1974. Pelexia triloba Lindl., Gen. Sp. Orchid. Pl.: 48311. 1840.

Figuras 2A-E e 6E-F.

Erva terrícola. Caule inconspícuo, 2-3 folhas, coberto por bainhas. Folhas $12,5-18 \times 2,4-3,7 \mathrm{~cm}$, verdes com máculas brancas, membranáceas, eretas, lanceoladas, ápice agudo, base atenuada; pecíolo $16-19 \mathrm{~cm}$ compr. Racemo terminal, verde, ereto; pedúnculo ca. $42 \mathrm{~cm}$ compr.; raque ca. $7 \mathrm{~cm}$ compr.; brácteas florais $0,9-1,8 \mathrm{~cm}$ compr. Flores verdes, membranáceas, ressupinadas, glabras; pedicelo incluindo ovário $1-1,3$ 
$\mathrm{cm}$ compr. Sépalas lanceoladas, ápice agudo, base truncada, margem inteira; sépala dorsal 8-9,3 × 2,22,4 mm; sépalas laterais $8,5-10 \times 0,8-1,3 \mathrm{~mm}$. Pétalas 5-7,5 × 1,5-2 mm, lanceoladas, ápice agudo, base truncada, margem inteira. Labelo 5-7 × 3-3,6 mm, trilobado, base atenuada, margem inteira, glabro; lobo terminal 4,5-5 × 2-3 $\mathrm{mm}$, lanceolado, ápice cuspidado; lobos laterais $1-1,3 \mathrm{~mm}$ larg., lanceolados, ápice arredondado. Coluna 4,5-5 mm compr.; antera 2,3-2,8 × 2-2,2 mm, obovada, verde; polínias 2, obovadas. Calcar 2,5-3,5 mm, obovado.

Material examinado - 1 jul. 2011, L.C. Marinho et al. 68 (HUESBVC).

Eltroplectris triloba ocorre apenas nos estados do Espírito Santo, Rio de Janeiro, São Paulo e Bahia (Cunha \& Forzza 2007; Barros et al. 2012); neste último, havia sido citada apenas para a região da Chapada Diamantina, nos municípios de Palmeiras e Rio de Contas (Smidt 2003; Toscano-de-Brito \& Cribb 2005). É muito semelhante a Prescottia stachyodes, podendo ser diferenciada desta pelas folhas de base atenuada com máculas brancas e pelas flores calcaradas e ressupinadas, o que não ocorre em $P$. stachyodes. Os indivíduos foram encontrados dispostos em pequenas populações isoladas em locais sombreados. Floresce entre os meses de junho e agosto.

5. Gomesa barbata (Lindl.) M.W.Chase \& N.H.Williams, Ann. Bot. 104: 395. 2009. Oncidium barbatum Lindl., Coll. Bot.: t. 27. 1821.

Figuras 2F-L e $6 \mathrm{G}-\mathrm{H}$.

Erva epífita. Pseudobulbo 1,5-3,5 cm compr., achatado, unifoliado, com folhas laterais na base, verdes. Folhas 6-12(-28.,3) × 1,2-1,8 cm, verdes, papiráceas, oblongas, ápice retuso, base truncada. Panícula lateral, pendente, verde; pedúnculo $21-32 \mathrm{~cm}$ compr.; raque 19-23,5(-37) cm compr.; brácteas florais 3-6 mm compr. Flores amarelas com máculas marrons, membranáceas, ressupinadas, glabras; pedicelo (incluindo o ovário) 0,6-1.9 cm compr. Sépalas lanceoladas, ápice agudo, base atenuada, margem inteira ondulada; sépala dorsal $1-1,4 \mathrm{~cm} \times$ 4-5 mm; sépalas laterais $1-1,8 \mathrm{~cm} \times 3-5 \mathrm{~mm}$, conatas até $1 / 2$ do comprimento. Pétalas $1-1,8 \mathrm{~cm} \times 4-6 \mathrm{~mm}$, lanceoladas, ápice agudo, base atenuada, margem inteira, ondulada. Labelo trilobado, base atenuada; calo central formando uma quilha central elevada e quatro projeções laterais; lobo mediano 3-5 × 3-4 mm, deltoide, ápice cuspidado, base atenuada, margem ciliada; lobos laterais ca. $7 \times 9 \mathrm{~mm}$, reniformes, ápice arredondado, base atenuada. Coluna 4-5 $\mathrm{mm}$ compr., com um par de aurículas arredondadas; tábula infraestigmática amarela; antera ca. $1.8 \mathrm{~mm}$ compr., amarela, orbiculares; polínias 2, ovadas.

Material examinado - 14 mar. 2011, L.C. Marinho \& C.O. Azevedo 24 (HUESBVC).
Através de estudos moleculares, uma série de mudanças nomenclaturais foram propostas para $o$ gênero Oncidium s.l. Dessa forma, a espécie aqui citada como Gomesa barbata segue a proposta de Chase et al. (2009). A espécie encontra-se amplamente distribuída na Região Nordeste e em Minas Gerais (Barros et al. 2012). Alguns espécimes apresentaram grande variação quanto ao tamanho do lobo terminal do labelo e coloração. Na porção mais seca da Reserva, os espécimes apresentam o lobo central menor e flores mais clara. Diferencia-se das espécies afins por apresentar o lobo terminal reduzido (Pabst \& Dungs 1977). Pode ser facilmente reconhecida dentre as demais epífitas da Reserva por apresentar inflorescência de grande porte, flores amarelas com máculas marrons e lobo terminal do labelo ciliado. Floresce de março a junho.

6. Oeceoclades maculata (Lindl.) Lindl., Gen. Sp. Orchid. P1.: 237. 1833. Angraecum maculatum Lindl., Coll. Bot. 3: t. 15. 1821.

Figuras $3 \mathrm{~A}-\mathrm{G}$ e $6 \mathrm{I}-\mathrm{J}$.

Erva terrícola. Pseudobulbo 3-5 cm compr., ovoide, unifoliado, coberto por bainhas. Folhas 10-23(-32) $\times$ $2-4(-5,5) \mathrm{cm}$, verdes, com máculas assimétricas escurecidas, sésseis, coriáceas, lanceoladas, ápice agudo, base atenuada. Racemo lateral, ereto; pedúnculo (5,5)19-30 cm compr., verde; raque 5-10 cm compr., vinácea; brácteas florais $1-1,5 \mathrm{~cm}$ compr. Flores creme-esverdeadas, membranáceas, ressupinadas, calcaradas, glabras; pedicelo (incluindo ovário) 0,8-1,7 $\mathrm{cm}$ compr. Sépalas com ápice agudo, base truncada, margens inteiras; sépala dorsal $8-10 \times 2-3 \mathrm{~mm}$, oblonga; sépalas laterais $8-9 \times 1,5-2 \mathrm{~mm}$, oblonga levemente falcada na base. Pétalas 9-11 $\times 3-4 \mathrm{~mm}$, lanceolada, ápice agudo, base truncada, margem inteira. Labelo trilobado, base atenuada; lobos laterais 2,5-3 mm compr., alvos, ápice obtuso, margem inteira; lobo terminal 3-4 $\mathrm{mm}$ compr., alvo com máculas róseas, ápice retuso, margem ondulada. Coluna 5-6 mm compr.; antera 1,8-2 mm compr.; polínias 2, ovadas. Calcar 5-7 mm compr., vináceo, claviforme.

Material examinado - 19 jun. 2010, L.C. Marinho et al. 2 (HUESBVC).

Oeceoclades maculata ocorre em todos os estados do Brasil, com exceção do Amapá (Pabst \& Dungs 1975; Barros et al. 2012). A espécie é diferenciada das outras orquídeas terrícolas da Reserva pela presença de pseudobulbos, folhas coriáceas com máculas escuras e labelo com duas máculas róseas, além do calcar robusto. Floresce entre janeiro e julho.

7. Polystachya estrellensis Rchb. f., Linnaea 25: 231. 1852.

Figuras 3H-M e 7A-B.

Erva epífita. Pseudobulbo 1-2 cm compr., ovoide, ereto, verde, multifoliados, coberto por bainhas. Folhas 5,4-20 × 1,3-3,5 cm, verdes, sésseis, papiráceas, lanceoladas, ápice agudo, base atenuada. Racemo 
terminal, ereto; pedúnculo $5-13,5(-20) \mathrm{cm}$ compr., marrom, cilíndrico; raque 12,5-19,5(-33) cm compr., verde, cilíndrico. Flores verdes, sésseis, carnosas, não ressupinadas, glabras; pedicelo incluindo ovário 1,3-4 $\mathrm{mm}$ compr. Sépalas côncavas, ovadas, ápice agudo, base truncada, margem inteira; sépala dorsal 2,2-2,5 $\times$
3-3,5 mm; sépalas laterais $2,5 \times 3-4 \mathrm{~mm}$. Pétalas $1-1,3 \times 3-3,4 \mathrm{~mm}$, lineares a oblongas, ápice arredondado, base truncada, margem inteira. Labelo trilobado, base atenuada, margem inteira; calo basal com pseudopólen; lobo terminal ca. 3,5 × 1,6 mm, ápice arredondado; lobos laterais eretos, ápice obtuso.

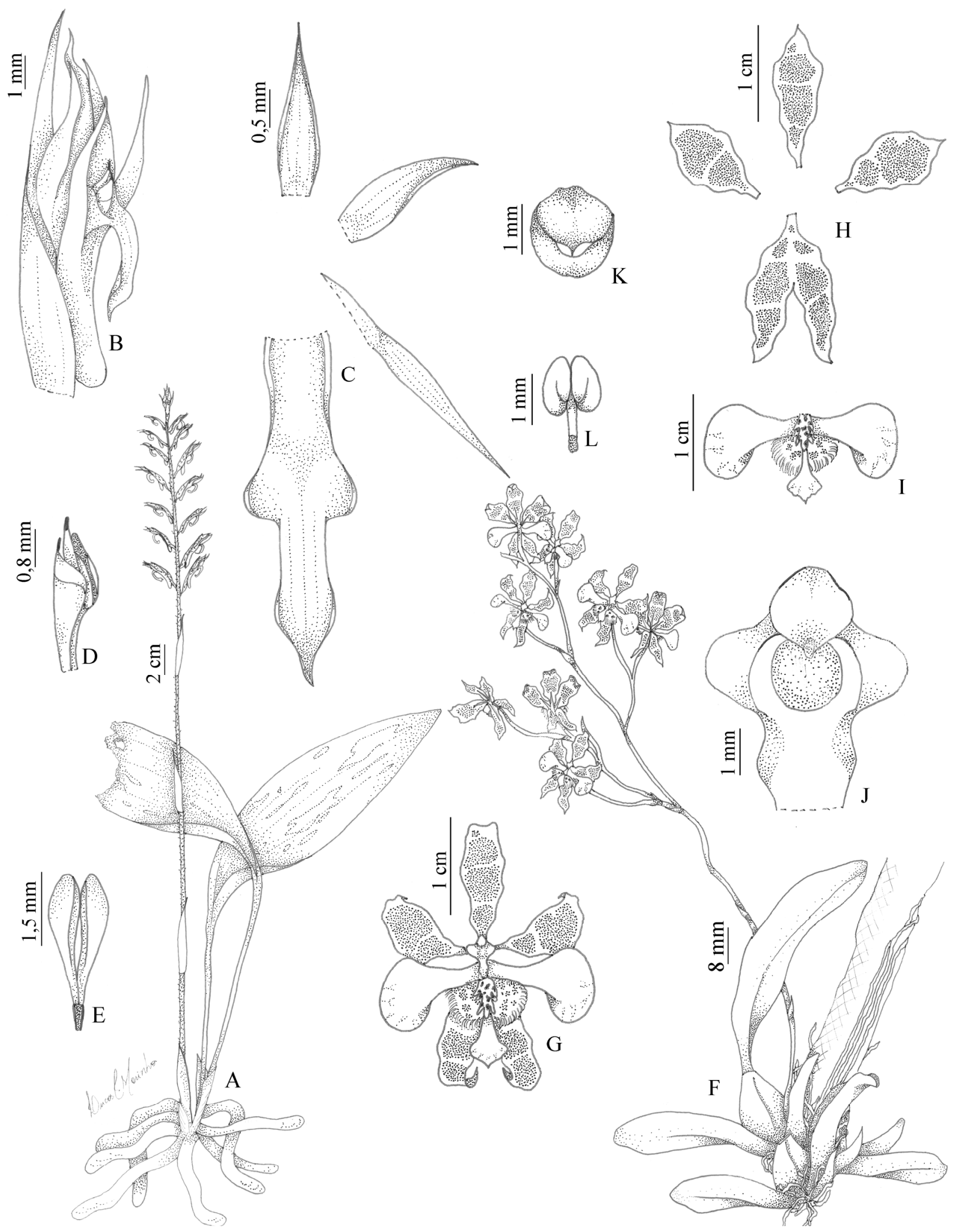

Figura 2. A-E. Eltroplectris triloba: A- hábito; B- flor; C- perianto; D- coluna; E- polinário. F-L. Gomesa barbata: F- hábito; G- flor; H- sépalas e pétalas; I- labelo, vista frontal; J- coluna; K- antera; L- polinário. 


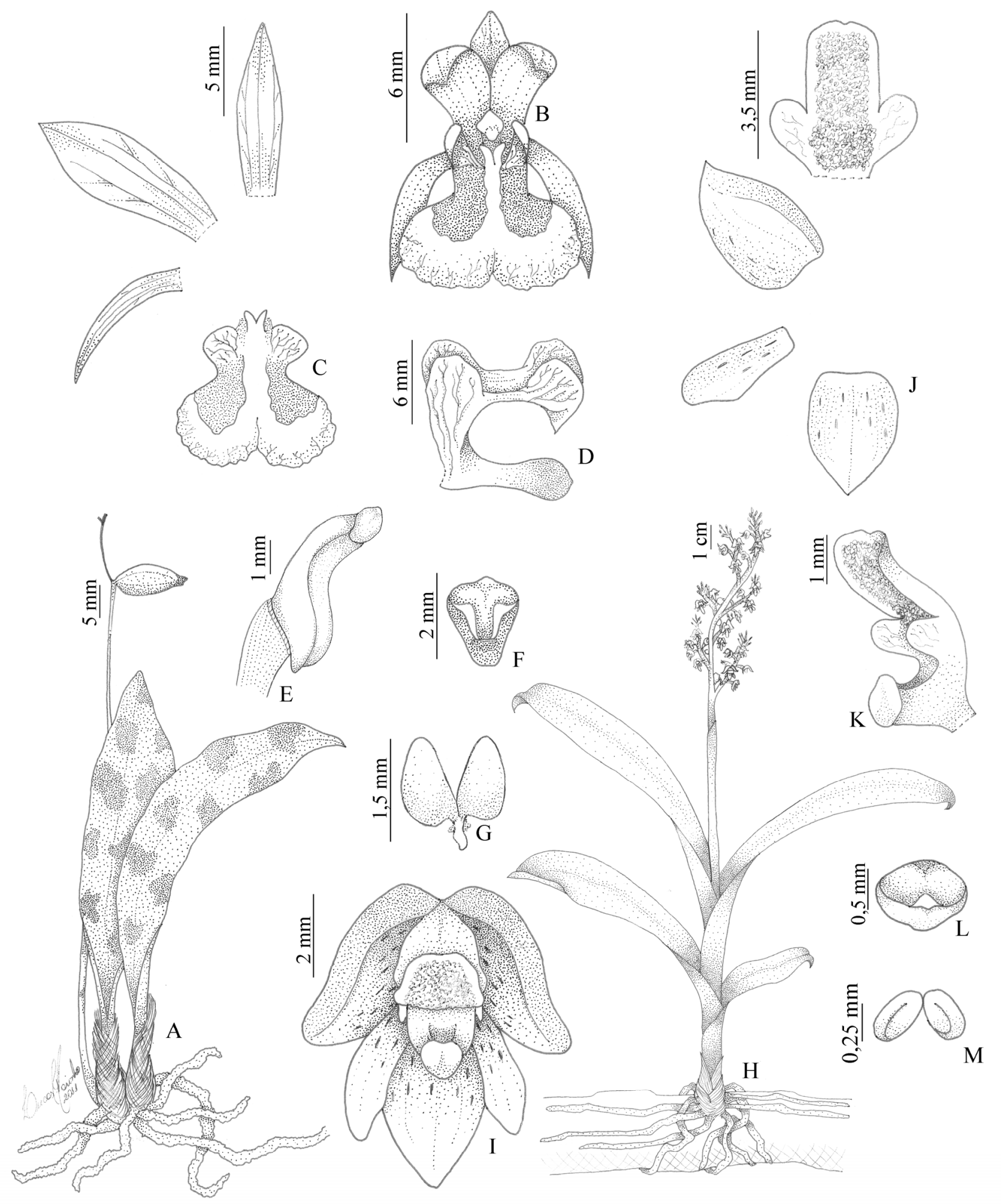

Figura 3. A-G. Oeceoclades maculata:A- hábito; B- flor; C- perianto; D- labelo e calcar, vista lateral; E- coluna; F- antera; G- polinário. H-M. Polystachya estrellensis: H- hábito; I- flor; J- perianto; K- labelo e coluna, vista lateral; L- antera; M- polínias.

Coluna 1-2 mm compr.; antera ca. $1 \mathrm{~mm}$ compr., deltoide, amarela; polínias 2, orbiculares.

Material examinado - 23 mar. 2011, L.C. Marinho \& C.O. Azevedo 27 (HUESBVC).

Polystachya estrellensis ocorre em todas as Regiões brasileiras (Cardoso \& Israel 2005; Cunha \& Forzza
2007; Abreu et al. 2011; Barros et al. 2012), sendo muitas vezes confundida com $P$. concreta (Jacq.) Garay \& H.R.Sweet. As duas espécies podem ser diferenciadas pelas sépalas mais angulosas, pétalas mais afiladas e lobos laterais subquadráticos em P. concreta (Pansarin \& Amaral 2006). Diferencia-se 
das demais epífitas pelas flores verdes e não ressupinadas e pela presença do pseudopólen. O mesmo foi observado na Reserva do Poço Escuro, onde a espécie foi encontrada tanto na área mais úmida quanto na área mais seca. Floresce nos meses de março e abril.

8. Prescottia stachyodes (Sw.) Lindl., Edwards's Bot. Reg. 22: sub. t. 1915 ('t. 1916'). 1836. Cranichis stachyodes Sw., Prodr.: 120. 1788.

Figuras 4A-E e 7C-D.

Erva terrícola. Caule inconspícuo, 2 ou 3 folhas, coberto por bainhas. Folhas 8,5-20 × 2,5-10 cm, verdes com linha branca na margem, membranáceas, eretas, lanceoladas a ovadas, ápice agudo, base obtusa; pecíolo $18-20 \mathrm{~cm}$ compr. Racemo terminal, ereto, verde; pedúnculo 40-53(-72) cm compr.; raque 20-23 cm compr.; brácteas florais 4-6 × 1,5-2,5 mm. Flores não ressupinadas, glabras; pedicelo (incluindo ovário) 5-7 mm compr. Sépalas verde amarronzadas, membranáceas, revolutas, ovadas, margem inteira; sépala dorsal 3,5-4 × 1,5-2 mm, ápice obtuso, base truncada; sépalas laterais ca. $5 \times 1-1,4 \mathrm{~mm}$, ápice obtuso, base concrescida. Pétalas $3-3,5 \times$ ca. $1 \mathrm{~mm}$, verde-amarronzadas, membranáceas, revolutas, lineares, ápice agudo, base truncada, margem inteira. Labelo 4,5-5 × 2,5-4 mm, verde, cuculado, carnoso, ovado, ápice agudo, base truncada biauriculada, margem involuta. Coluna ca. 1,7 mm compr.; antera amarela ca. $1 \mathrm{~mm}$ compr., deltoide; polínias 4, obovadas.

Material examinado - 19 jun. 2011, L.C. Marinho et al. 3 (HUESBVC).

Prescottia stachyodes ocorre nas Américas Central e do Sul (Pabst \& Dungs 1975; Azevedo 2009), sendo citada para o Distrito Federal e para todos os estados das Regiões Sul e Sudeste, além do Amazonas, Pará, Ceará, Paraíba, Pernambuco, Alagoas e Bahia (Menini Neto et al. 2007a; Abreu et al. 2011; Macagnan et al. 2011; Barros et al. 2012). Na Bahia, foi citada para Mucugê, na Chapada Diamantina (Azevedo \& van den Berg 2007) e para o sul do estado, no município de Camacan (Amorim et al. 2009). Possui uma extensa lista de sinônimos devido à grande variação morfológica que pode ser observada em decorrência do ambiente em que ocorre (Azevedo \& van den Berg 2007). Pode ser reconhecida dentre as espécies da Reserva pelas flores verdes, não ressupinadas, sépalas e pétalas revolutas, além do labelo cuculado. Foi coletada em terrenos alagados no interior da mata, podendo ser encontrada com flor entre os meses de junho e setembro.

9. Psilochilus modestus Barb. Rodr., Gen. Sp. Orchid. 2: 273. 1882. Pogonia modesta (Barb. Rodr.) Cogn., Fl. Bras. 3: 133. 1893.

Figuras 4F-I e 7E.

Erva terrícola. Caule 9,5-22,5 cm compr., vináceo, multifoliado, ereto. Folhas $3-10 \times 1,2-3,6 \mathrm{~cm}$, verdes na face adaxial, vináceas na face abaxial, pecioladas, papiráceas, ovadas, ápice agudo, base arredondada, ao longo da extensão do caule, dísticas; bainhas foliares 3-4 cm compr., verdes. Racemo terminal, ereto. Flores membranáceas, ressupinadas, pedicelo (incluindo ovário) 1,5-2,4 cm compr., glabras. Sépalas esverdeadas, ápice agudo, base atenuada, margem inteira; sépala dorsal 2,3-2,6 ×0,3-0,5 cm, lanceolada; sépalas laterais $2,1-2,4 \mathrm{~cm} \times 4-6 \mathrm{~mm}$, falcadas. Pétalas 2-2,5 cm $\times 3-4 \mathrm{~mm}$, alvas, lanceoladas, falcadas, ápice agudo, base atenuada, margem inteira. Labelo trilobado, ca. $2,2 \times 1 \mathrm{~cm}$, alvo, base atenuada; lobo terminal ca. $8 \mathrm{~mm}$ compr., deltoide, ápice arredondado, margem inteira, ondulada, com nuances lilás nas extremidades; lobos laterais ca. $2 \mathrm{~mm}$ compr., triangulares, ápice agudo, margem inteira. Coluna ca. 2 cm compr., falciforme; antera oblonga, alva; polínias 4 , cilíndricas.

Material examinado - 15 dez. 2010, L.C. Marinho \& C.O. Azevedo 14 (HUESBVC).

Psilochilus modestus distribui-se ao longo das Américas Central e do Sul, na Colômbia, Equador, Nicarágua e Venezuela (Rothacker 2007), sendo citada para o Brasil em todos os estados das Regiões Sul e Sudeste (Pabst \& Dungs 1975; Menini Neto et al. 2004; Rocha \& Waechter 2006; Menini Neto et al. 2007a; Pansarin \& Pansarin 2008; Magalhães \& Maimoni-Rodella 2012, Barros et al. 2012), além do Amazonas (Barros et al. 2012), e, posteriormente, coletada na RPPN de Serra Bonita, no sul da Bahia, no município de Camacan (Amorim et al. 2009). Além de $P$. modestus, apenas $P$. dusenianus Kraenzl. ex Garay \& Dunst. ocorre no Brasil (Pabst \& Dungs 1975, Barros et al. 2012), sendo diferenciada pelo labelo com uma constrição no lobo terminal e coluna não falciforme em P. dusenianus (Pabst \& Dungs 1975). $\mathrm{Na}$ Reserva, é facilmente diferenciada das demais espécies terrícolas por apresentar folhas ao longo do caule. São plantas que se desenvolvem em locais sombreados e que possuem flores de vida curta florescendo entre setembro e fevereiro.

10.Sarcoglottis curvisepala Szlach. \& Rutk., Ann. Bot. Fenn. 34: 277. 1997.

Figuras $4 \mathrm{~J}-\mathrm{N}$ e $7 \mathrm{~F}-\mathrm{G}$.

Erva rupícola. Caule inconspícuo, 2 ou 3 folhas. Folhas não vistas. Inflorescência em racemo, terminal, ereto; pedúnculo ca. $39 \mathrm{~cm}$ compr., verde; raque ca. $6 \mathrm{~cm}$ compr., verde, glabra; brácteas florais 1,2-1,4 $\times \quad 2,7-3 \mathrm{~cm}$. Flores verdes, membranáceas, ressupinadas; pedicelo (incluindo ovário) 3-4 cm compr. Sépalas carnosas, falcadas, ápice obtuso, base truncada, margem inteira, externamente pilosa na base; sépala dorsal $1,8-2,4 \mathrm{~cm} \times 5-6 \mathrm{~mm}$, conata na base às sépalas laterais; sépalas laterais 2,6-2,8 cm $\times 6-7 \mathrm{~mm}$, conatas até $1 / 3$ do comprimento. Pétalas $1,5-1,8 \mathrm{~cm} \times$ 3-4 mm, lanceoladas, ápice obtuso, base truncada. Labelo 2,5-2,7 × 1-1,2 cm, trilobado, base truncada, falcado, constrito no centro; calosidade na porção 
mediana do lobo terminal; lobo terminal $0,8-1 \times 1-1,2 \mathrm{~cm}$, ereto, deltoide, ápice obtuso; lobos laterais eretos, ápice obtuso. Coluna 3,7-4 cm compr., falcada; antera 1,5-1,7 cm compr., verde; polínias 2 , clavada.

Material examinado - 2 jul. 2011, L.C. Marinho et al. 123 (HUESBVC).

Sarcoglottis curvisepala foi citada para o Brasil apenas em 1997 (Szlachetko \& Rutkowski 1997) e, até o presente, havia sido coletada no Distrito Federal e nos estados de Minas Gerais e Mato Grosso do Sul (Szlachetko \& Rutkowski 1997; Batista \& Bianchetti 2003; Rodriguez, et al. 2009; Barros et al. 2012). Na Bahia, até o momento, havia sido registrada apenas para a região da Chapada Diamantina (Smidt 2003;
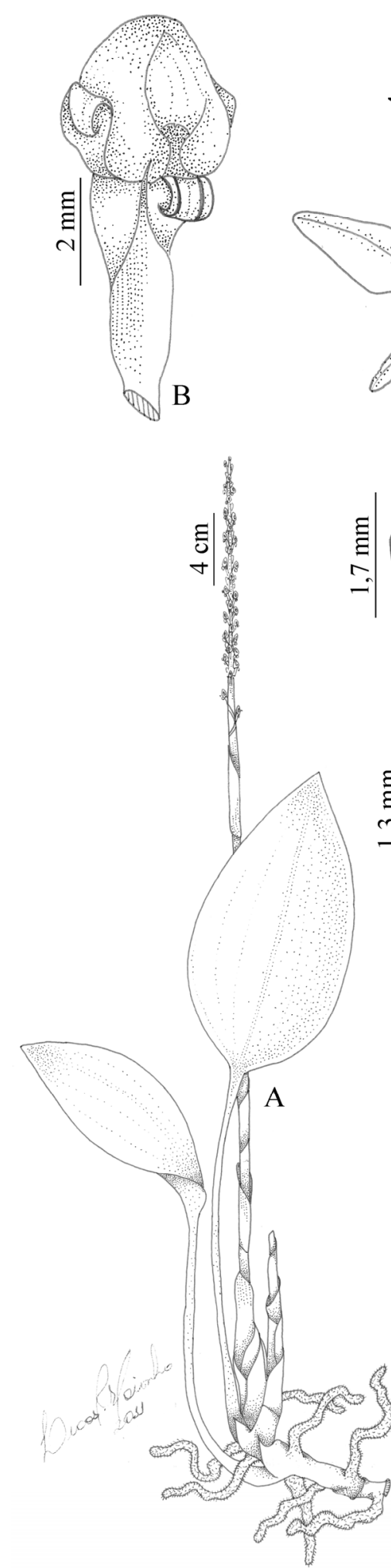
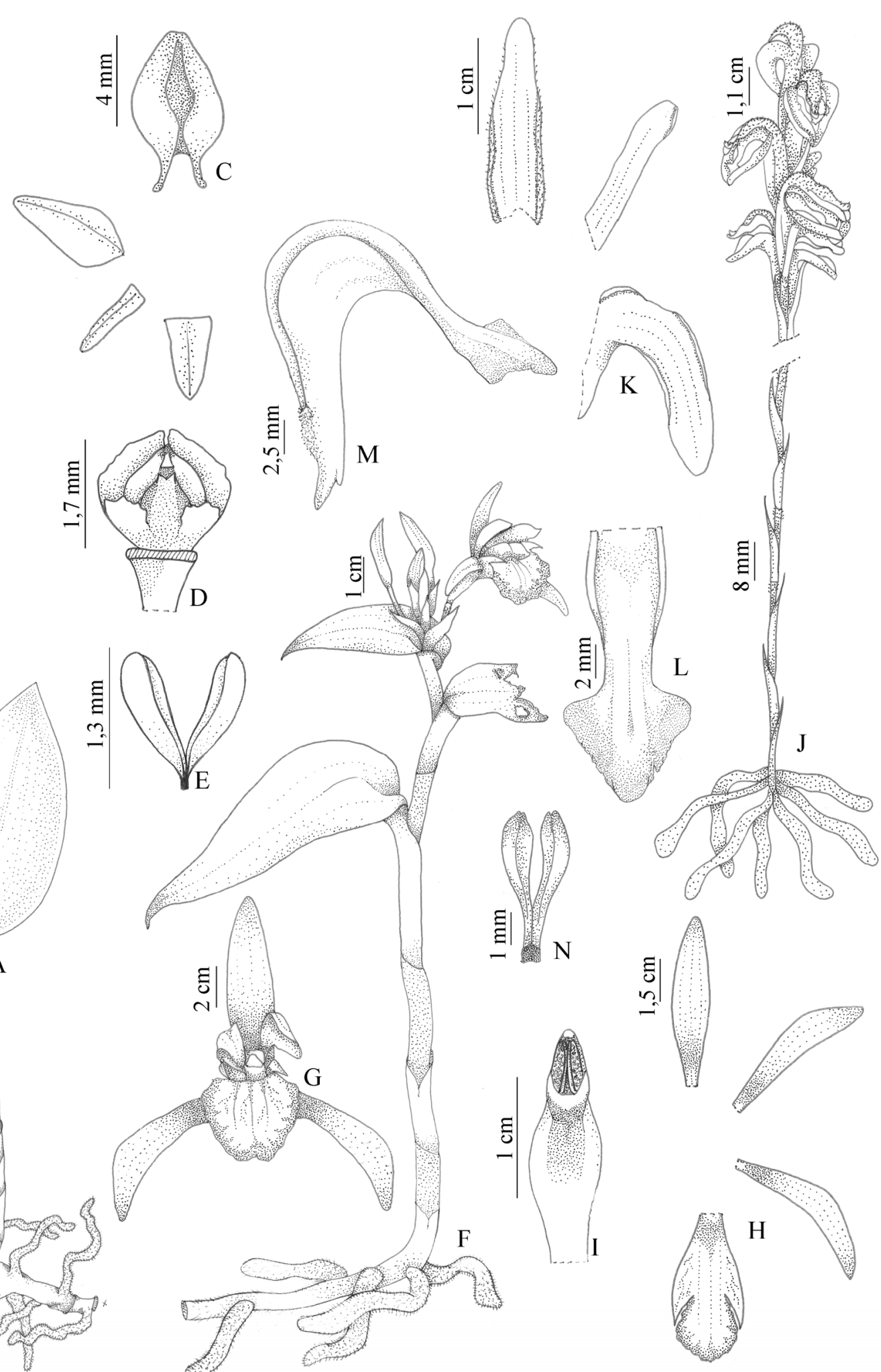

Figura 4. A-E. Prescottia stachyodes: A- hábito; B- flor; C- perianto; D- coluna; E- polinário. F-I. Psilochilus modestus: F- hábito; G- flor; H- perianto; I- coluna. J-N. Sarcoglottis curvisepala: J- hábito; K- sépalas e pétala; L- labelo estendido; M- labelo em vista lateral; N- polinário. 
Toscano-de-Brito \& Cribb 2005). Quando fértil, $S$. curvisepala pode ser diferenciada de $S$. fasciculata (Vell.) Schlecht e S. grandiflora (Lindl.) K1. pelas sépalas muito longas e fortemente falcadas e o labelo constrito no centro (Szlachetko \& Rutkowsk 1997). Na Reserva, a espécie diferencia-se das demais terrícolas pelas flores verdes e pilosas e sépalas e pétalas extremamente carnosas. Floresce nos meses de julho e agosto em ambientes rochosos.

11.Stelis aprica Lindl., Companion Bot. Mag. 2: 353. 1837.

Figuras $5 \mathrm{~A}-\mathrm{F}$ e $7 \mathrm{H}-\mathrm{J}$.

Erva epífita. Ramicaule 1,5-4,5 cm compr., unifoliado, verde, ereto, cilíndrico. Folhas 4-6,5 $\times$ 0,5-1 cm, verdes, sésseis, coriáceas, lanceoladas a lineares, ápice retuso, base atenuada. Inflorescência em racemo, terminal, amarelo-esverdeado; pedúnculo inconspícuo; raque 2,5-5 cm compr., pendente; brácteas florais $0,8-1 \mathrm{~mm}$ compr. Flores amareloesverdeadas, membranáceas, ressupinadas; pedicelo inconspícuo. Sépalas 1-1,5 × 1-1,5 mm, simétricas, côncavas, ovadas, ápice agudo, base truncada, margem inteira, levemente pilosas, livres. Pétalas $0,4-0,5 \times$ 0,4-0,5 mm, côncavas, deltoides, ápice arredondado, base truncada, margem inteira, glabras. Labelo $0,5-0,8$ $\times$ ca. $0,5 \mathrm{~mm}$, base truncada, glabro, trilobado; lobo terminal acuminado, inconspícuo; lobos laterais obtusos, inconspícuos. Coluna 0,4-0,9 × 0,5-1 mm; antera ca. $0,25 \mathrm{~mm}$ compr., orbicular, amarela esverdeadas; polínias 2, orbiculares a ovadas.

Material examinado - 19 jun. 2010, L.C. Marinho et al. 1 (HUESBVC).

Stelis aprica é registrada para os estados do Espírito Santo, Minas Gerais, Rio de Janeiro, São Paulo, Paraná, Santa Catarina (Pabst \& Dungs 1975; Menini Neto et al. 2007a,b; Abreu et al. 2011) e Bahia, onde foi registrada para Catolés, na Chapada Diamantina (Toscano-de-Brito \& Queiroz 2003) e Camacan, na RPPN de Serra Bonita ao sul do estado (Amorim et al. 2009). Pode ser confundida com S. intermedia Poepp. $\&$ Endl., diferenciado-se desta pelo labelo em forma de gancho e ápice acuminado (Colla 2011). Na Reserva, é distinguida pelas folhas lanceoladas a lineares e coriáceas, flores amarelo-esverdeadas diminutas e pela simetria entre suas sépalas. Santa-Jiménez et al. (2009) afirmam que $S$. aprica é encontrada, geralmente, associada a substratos que possuem musgos e liquens, o que poderia explicar a ocorrência da espécie apenas na porção úmida da Reserva. Encontrada em flor no mês de junho.

12.Trichocentrum pumilum (Lindl.) M.W.Chase \& N.H.Williams, Lindleyana 16: 137. 2001. Oncidium pumilum Lindl., Bot. Reg. 11: t. 920. 1825.

Figuras 5G-K e 7K-L.

Erva epífita. Pseudobulbo inconspícuo. Folhas 5,5$16,2 \times 1,2-4 \mathrm{~cm}$, verdes, sésseis, membranáceas, lanceoladas, ápice agudo, base atenuada. Panícula lateral, ereta, verde; pedúnculo 3-7 cm compr.; raque 4,8-19(-29) cm compr.; brácteas florais 3-5 mm compr. Flores amarelas com máculas marrons, membranáceas, ressupinadas; pedicelo (incluindo ovário) 1-3 mm compr. Sépalas obovadas, ápice arredondado, base truncada, margem inteira, glabras; sépala dorsal 2,5-3 × 1-1,5 mm; sépalas laterais 2-2,5 $\times$ ca. $1 \mathrm{~mm}$. Pétalas $2-2,5 \times 1-1,5 \mathrm{~mm}$, espatuladas, ápice obtuso, base truncada, margem inteira, glabras. Labelo ciliado, trilobado; calo central tetralobado com lobos livres; lobo terminal 1,3-1,4 mm compr.; lobos laterais 1,2-1,3 $\mathrm{mm}$ compr. Coluna 1,3-1,7 mm compr., com um par de aurículas alongadas falcadas; tábula infraestigmática alaranjada; antera ca. $1 \mathrm{~mm}$ compr., obovada, amarela; polínias 2, ovadas.

Material examinado - 27 nov. 2010, L.C. Marinho et al. 7 (HUESBVC); 13 mar. 1999, A.O. Soares-Filho 219 (HUESBVC).

Trichocentrum pumilum é registrada em todos os estados das Regiões Sul e Sudeste, além dos estados do Pará, Bahia, Mato Grosso e Goiás (Pabst \& Dungs 1977; Cardoso \& Israel 2005; Buzzato et al. 2007; Schuster et al. 2010; Barros et al. 2012). Pode ser facilmente distinguida das espécies próximas pelo labelo apresentando calo central tetralobado e lobos laterais de tamanho similar ao lobo central (Pabst \& Dungs 1977). Como Gomesa barbata, T. pumilum apresenta flores amarelas com máculas marrons, porém suas flores e inflorescência são menores. A espécie ocorre tanto em árvores de grande porte quanto em arbustos com predominância na área mais seca da Reserva. Floresce entre setembro e novembro.

\section{Agradecimentos}

Os autores agradecem a Aline M. de Souza e Anderson F. P. Machado, pelo auxílio durante as coletas, e ao Conselho Nacional de Desenvolvimento Científico e Tecnológico (CNPq), pela bolsa de iniciação científica concedida ao primeiro autor.

\section{REFERÊNCIAS}

Abreu, N.L.; Menini Neto, L. \& Konno, T.U.P. 2011. Orchidaceae das Serras Negra e do Funil, Rio Preto, Minas Gerais, e similaridade florística entre formações campestres e florestais do Brasil. Acta Botanica Brasilica 25: 58-70.

Amorim, A.M.; Jardim, J.G.; Lopes, M.M.M..; Fiaschi, P.; Borges, R.A.X.; Perdiz, R.O. \& Thomas, W.W. 2009. Angiosperms of montane forest areas in southern Bahia, Brazil. Biota Neotropica 9: 313-314.

Azevedo, C.O. 2009. Filogenia e Revisão Taxonômica do Gênero Prescottia Lindl. (Orchidaceae - Orchidoideae). Tese de Doutorado. Universidade Estadual de Feira de Santana.

Azevedo, C.O. \& Marinho, L.C. (no prelo). Novos registros de Orchidaceae para o Nordeste brasileiro: Acianthera tricarinata e Cyclopogon variegatus. Sitientibus série Ciências Biológicas 12: 339-344. 


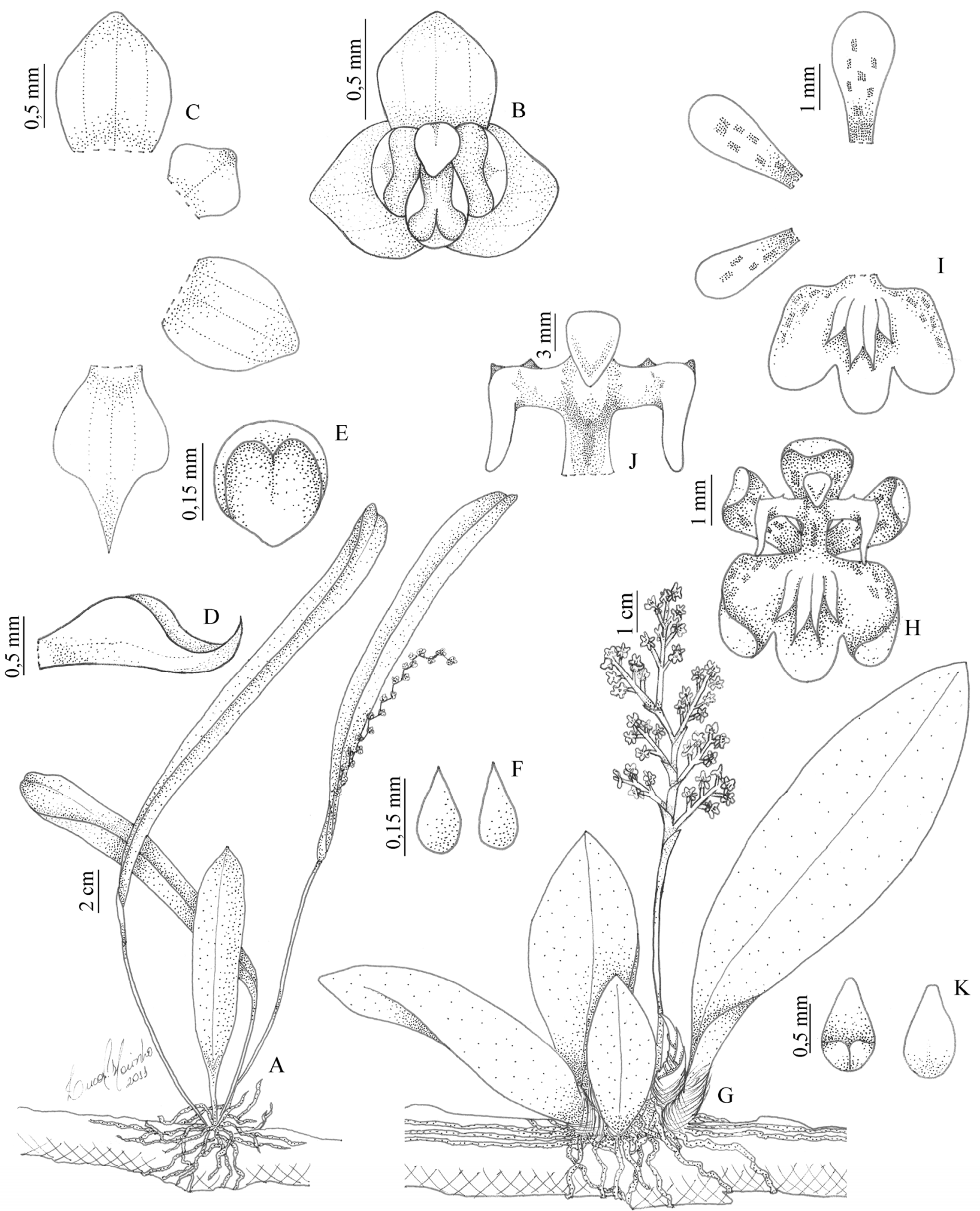

Figura 5. A-F. Stelis aprica:A- hábito; B- flor; C- perianto; D- labelo, vista lateral; E- antera; F- polínias. G-K. Trichocentrum pumilum: G- hábito; H- flor; I- perianto; J- coluna; K- antera.

Azevedo, C.O. \& van den Berg, C. 2007. A família Orchidaceae no Parque Municipal de Mucugê, Bahia, Brasil. Hoehnea 34: 147.

Barros, F.; Vinhos, F.; Rodrigues, V.T.; Barberena, F.F.V.A.; Fraga, C.N. \& Pessoa, E.M. 2012. Orchidaceae. In: Lista de Espécies da Flora do Brasil. Jardim Botânico do Rio de Janeiro. Disponível em http://floradobrasil.jbrj.gov.br/2012/FB020183; acesso em 20 abr. 2012.
Batista, J.A.N. \& Bianchetti, L.B. 2003. Lista atualizada das Orchidaceae do Distrito Federal. Acta Botanica Brasilica 17: 183-201.

Buzatto, C.R.; Freitas, E.M.; Silva, A.P.M. \& Lima, L.F.P. 2007. Levantamento florístico das Orchidaceae ocorrentes na fazenda São Maximiano, Município de Guaíba, Rio Grande do Sul. Revista Brasileira de Biociências 5: 19-25. 

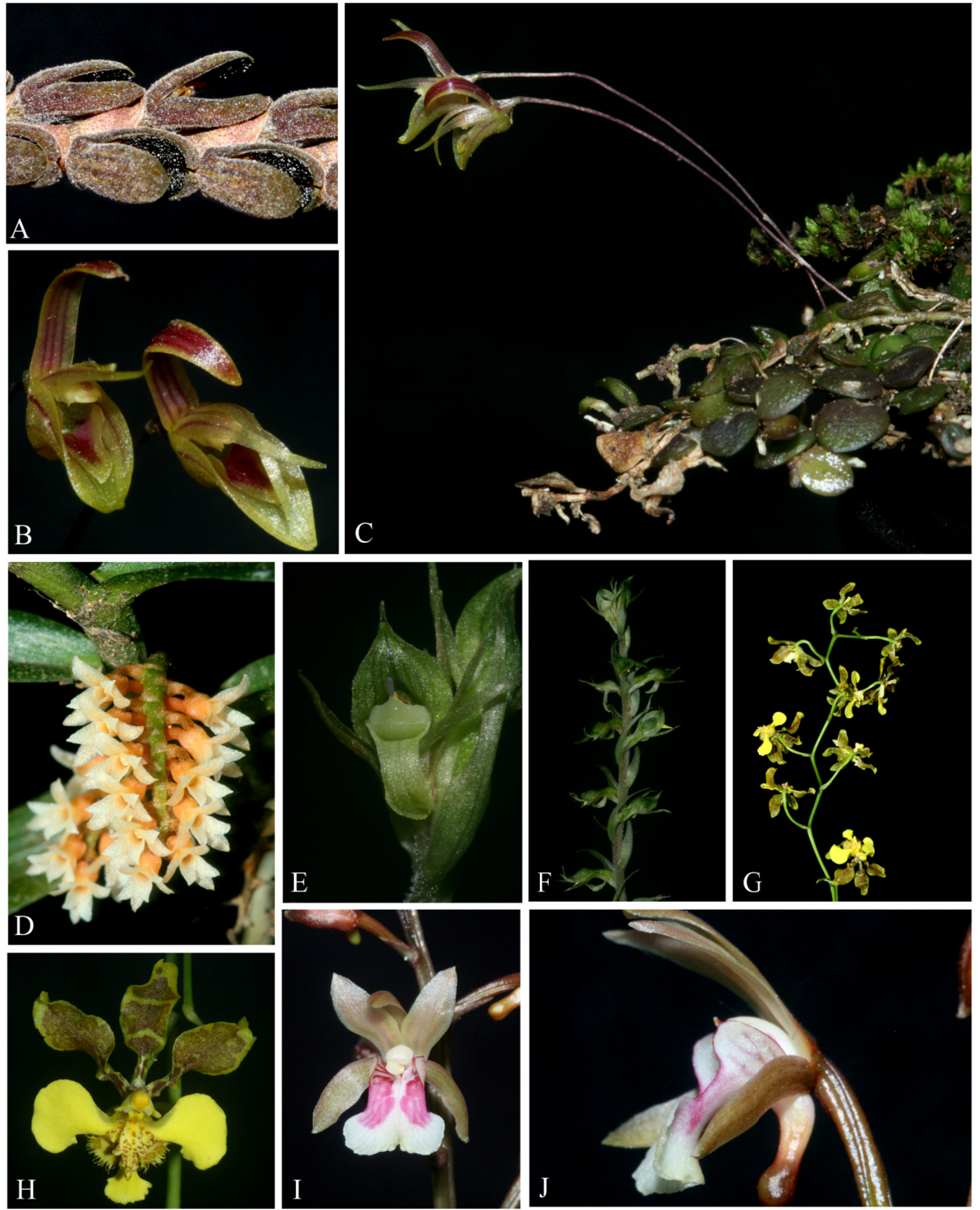

Figura 6. A- Acianthera saurocephala. B-C- Barbosella crassifolia. D- Campylocentrum micranthum. E-F- Eltroplectris triloba. G-H- Gomesa barbata. I-J- Oeceoclades maculata.

Buzatto, C.R.; Severo, B.M.A. \& Waechter, J.L. 2008 Composição florística e distribuição ecológica de epífitos vasculares na Floresta Nacional de Passo Fundo, Rio Grande do Sul. Iheringia série Botânica 63: 231-239.

Cardoso, J.C. \& Israel, M. 2005. Levantamento de espécies da família Orchidaceae em Águas de Sta. Bárbara (SP) e seu cultivo. Horticultura Brasileira 23: 169-173.
Colla, F.B. 2011. O gênero Stelis SW. (Orchidaceae) no Rio Grande do Sul, Brasil. Trabalho de conclusão de curso. Universidade Federal do Rio Grande do Sul.

Cunha, M.F.B. \& Forzza, R.C. 2007. Orchidaceae no Parque Natural Municipal da Prainha, RJ, Brasil. Acta Botanica Brasilica 21: 383-400. 

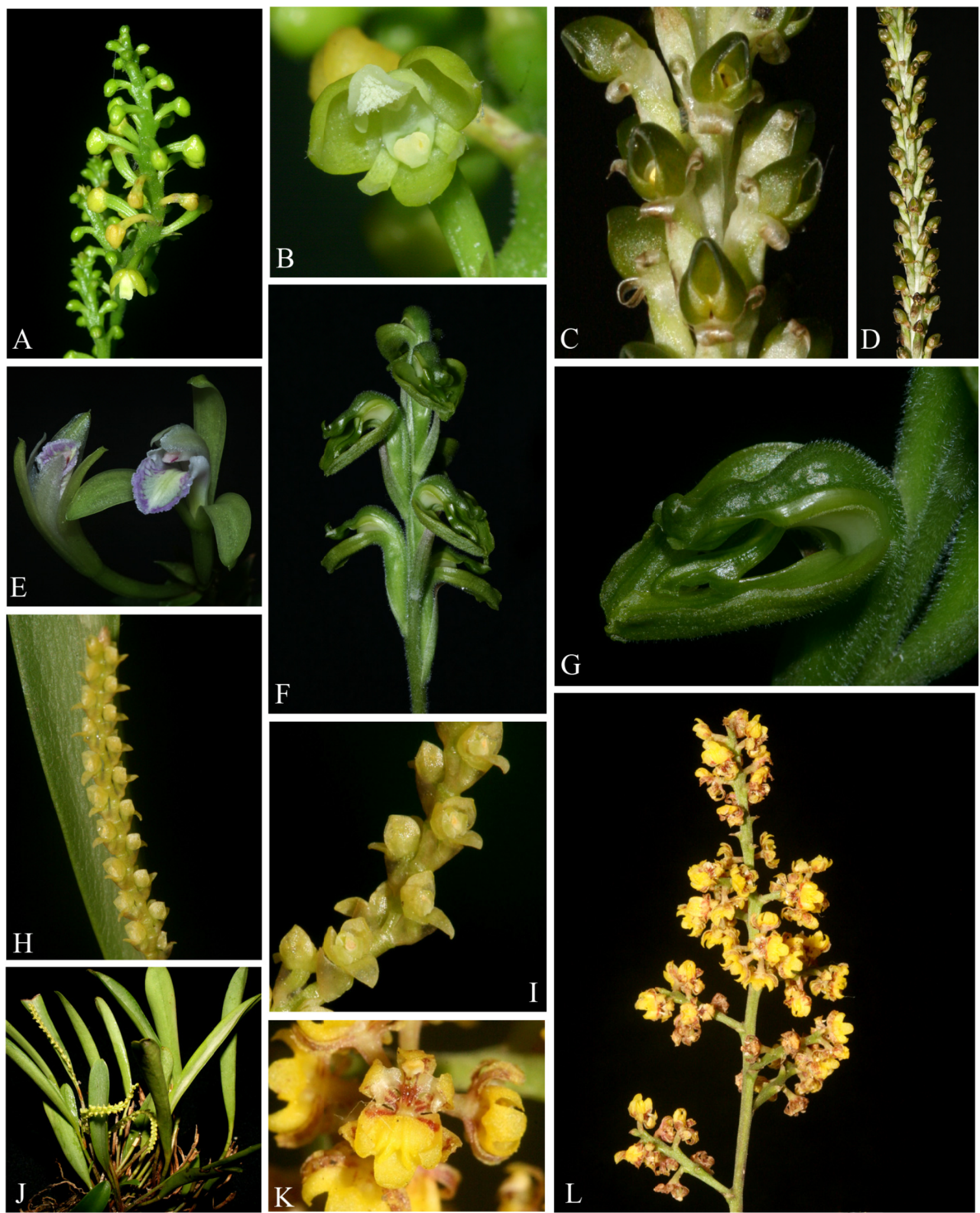

Figura 7. A-B- Polystachya estrellensis. C-D- Prescottia stachyodes. E- Psilochilus modestus. F-G- Sarcoglottis curvisepala. H-J- Stelis aprica. K-L- Trichocentrum pumilum.

Chase, M.W.; Williams, N.H.; Faria, A.D.; Neubig, K.M.; Amaral, M.C.E. \& Whitten, W.M. 2009. Floral convergence in Oncidiinae (Cymbidieae; Orchidaceae): an expanded concept of Gomesa and a new genus Nohawilliamsia. Annals of Botany 104: $387-402$.

Gentry, A.H. 1992. Tropical forest biodiversity: distributional patterns and their conservational significance. Oikos 63: 19-28.
Giongo, C. \& Waechter, J.L. 2004. Composição florística e estrutura comunitária de epífitos vasculares em uma floresta de galeria na Depressão Central do Rio Grande do Sul. Revista Brasileira de Botânica 27: 563-572.

Giulietti, A.M.; Harley, R.M.; Queiroz, L.P.; Wanderley, M.G.L. \& Pirani, J.R. 2000. Caracterização e endemismos nos campos rupestres da Cadeia do Espinhaço. In: T.B. Cavalcanti 
\& B.M.T. Walter (eds), Tópicos Atuais em Botânica. SBB/Embrapa, Brasília, p. 311-318.

Gonçalves, C.N. \& Waechter, J.L. 2011. Sinopse do gênero Acianthera Scheidw. (Orchidaceae) no Rio Grande do Sul, Brasil. Revista Brasileira de Biociências 9: 143-155.

Harley, R.M. \& Simmons, N.A. 1986. Florula of Mucuge: Chapada Diamantina - Bahia, Brazil. Royal Botanic Gardens, Kew, p. 228.

Loddiges, C. 1829. Botanical Cabinet; Consisting of Coloured Delineations of Plants from all Countries. Loddiges, London.

Macagnan, T.A.; Smidt, E.C. \& Azevedo, C.O. 2011. A subtribo Cranichidinae Lindl. (Orchidaceae) no estado do Paraná, Brasil. Revista Brasileira de Botânica 34: 447-461.

Magalhães, J.H.R. \& Maimoni-Rondella, R.C.S. 2012. Floristic composition of a freshwater swamp forest remnant in southeastern Brazil. Check List 8: 832-838.

Marinho, L.C. \& Azevedo, C.O. 2011. Acianthera saurocephala (Lodd.) Pridgeon \& M.W.Chase (Orchidaceae: Pleurothallidinae), novo registro para o Nordeste brasileiro. Revista Brasileira de Biociências 9: 554-557.

Menini Neto, L.; Almeida, V.R. \& Forzza, R.C. 2004. A família Orchidaceae na Reserva Biológica da Represa do Grama Descoberto, Minas Gerais, Brasil. Rodriguésia 55: 137-156.

Menini Neto, L.; Alves, R.J.V.; Barros, F. \& Forzza, R.C. 2007a. Orchidaceae do Parque Estadual de Ibitipoca, MG, Brasil. Acta Botanica Brasilica 21: 687-696.

Menini Neto, L.; Alves, R.J.V.; Barros, F. \& Forzza, R.C. 2007b.A subtribo Pleurothallidinae (Orchidaceae) no Parque Estadual de Ibitipoca, Minas Gerais, Brasil. Boletim de Botânica da Universidade de São Paulo 25: 253-278.

Mori, S.A.; Silva, L.A.; Lisboa, G. \& Coradin, L. 1989. Manual de Manejo do Herbário Fanerogâmico. 2 ed. CEPLAC, Ilhéus.

Pabst, G.F.J. \& Dungs, F. 1975. Orchidaceae Brasilienses. Vol. 1. Brücke-Verlag Kurt Schmersonw, Hildesheim.

Pabst, G.F.J. \& Dungs, F. 1977. Orchidaceae Brasilienses. Vol. 2. Brücke-Verlag Kurt Schmersonw, Hildesheim.

Pansarin, E.R. \& Amaral, M.C.E. 2006. Biologia reprodutiva e polinização de duas espécies de Polystachya Hook. no Sudeste do Brasil: evidência de pseudocleistogamia em Polystachyeae (Orchidaceae). Revista Brasileira de Botânica 29: 423-432.

Pansarin, E. R. \& Pansarin, L. M. 2008. A família Orchidaceae na Serra do Japi, São Paulo, Brasil. Rodriguésia 59: 99-111.

Queiroz, L.P.; Conceição, A.A. \& Giulietti, A.M. 2006. Nordeste Semi-Árido: caracterização geral e lista das fanerógamas. In: A.M. Giulietti, A.A. Conceição \& L.P. Queiroz (orgs), Diversidade e Caracterização das Fanerógamas do Semi-Árido Brasileiro. Vol. 1. Associação Plantas do Nordeste, Recife, p. 15-359.

Rocha, F.S. \& Waechter, J.L. 2006. Sinopse das Orchidaceae terrestres ocorrentes no litoral norte do Rio Grande do Sul, Brasil. Acta Botanica Brasilica 20: 71-86.

Rodriguez, D.P.; Barros, F.; Damasceno-Junior, G.A. \& Bortolotto, I.M. 2009. Levantamento da família Orchidaceae no Morro Santa Cruz, Municípios de Corumbá e Ladário, Mato Grosso do Sul, Brasil. Hoehnea 36: 613-636.

Romero-González, G.A. 2003. Orchidaceae. In: P.E. Berry, K. Holst \& K. Yatskievych (eds), Flora of the Venezuelan Guayana. Vol. 7. Missouri Botanical Garden, Saint Louis, p. $200-619$.
Rothacker, E.P. 2007. The Primitive Epidendroideae (Orchidaceae): phylogeny, character evolution and the systematics of Psilochilus (Triphoreae). Tese de Doutorado. The Ohio State University.

Santa-Jiménez, N.N.; Rodríguez, T.G. \& Marín, G.D.G. 2009. Estructura y composición de la comunidad de orquídeas en dos zonas de la Reserva Natural "La Montaña del Ocaso" Quimbaya-Quindío. Revista Universidad Del Quindio 19: 122134.

Schuster, H.; Pedroso-de-Moraes, C.; Souza-Leal, T.; CallegariCorreia, E.; Prezzi, L.E.; Domingues, E. \& Canassa, F. 2010. Diversidade de Orchidaceae da fazenda Cantagalo, município de Mogi-Mirim, São Paulo. Revista Brasileira de Biociências 8: 242-245.

Smidt, E.C. 2003. A subtribo Spiranthinae Lindl. (OrchidaceaeOrchidoideae) na Chapada Diamantina, Bahia, Brasil. Dissertação de Mestrado. Universidade Estadual de Feira de Santana.

Soares-Filho, A.O. 2000. Estudo Fitossociológico de Duas Florestas em Região Ecotonal no Planalto de Vitória da Conquista, Bahia, Brasil. Dissertação de Mestrado. Instituto de Biociências da Universidade de São Paulo.

Szlachetko, D.L. \& Rutkowski, P. 1997. Two new species of the genus Sarcoglottis (Orchidaceae) from Brazil. Annales Botanici Fennici 34: 275-279.

Thiers, B. 2012. Index Herbariorum: a global directory of public herbaria and associated staff. New York Botanical Garden's Virtual Herbarium. Disponível em http://sweetgum.nybg.org/ ih/; acesso em 2 maio 2012.

Toscano-de-Brito, A.L.V. 1995. Orchidaceae. In: B.L. Stannard (ed.), Flora of the Pico das Almas: Chapada Diamantina, Bahia, Brazil. Royal Botanic Gardens, Kew, p. 725-767.

Toscano-de-Brito, A.L.V. 1998. Orchidaceae. In: M.L.S. Guedes \& M.D. Orge (eds), Checklist das Espécies Vasculares do Morro do Pai Inácio (Palmeiras) e Serra da Chapadinha (Lençóis). Chapada Diamantina, Bahia, Brazil. UFBA, Salvador, p. 5354.

Toscano-de-Brito, A.L.V. \& Cribb, P. 2005. Orquídeas da Chapada Diamantina. Nova Fronteira, São Paulo.

Toscano-de-Brito, A.L.V. \& Queiroz, L.P. 2003. Orchidaceae. In: D.C. Zappi, E. Lucas, B.L. Stannard, E. Nic-Lughadha, J.R. Pirani, L.P. Queiroz, S. Atkins, D.J.N. Hind, A.M. Giulietti, R.M. Harley \& A.M. Carvalho (eds), Lista das plantas vasculares de Catolés, Chapada Diamantina, Bahia, Brasil. Boletim de Botânica da Universidade de São Paulo 21: 345389.

Van den Berg, C. \& Azevedo, C.O. 2005. Orquídeas. In: F.A. Junca, L. Funch \& W. Rocha (eds), Biodiversidade $e$ Conservação da Chapada Diamantina. Ministério do Meio Ambiente, Brasília, p. 195-208.

Veloso, H.P.; Rangel-Filho, A.L.R. \& Lima, J.C.A. 1991. Classificação da Vegetação Brasileira, Adaptada a um Sistema Universal. Fundação Instituto Brasileiro de Geografia e Estatística, Rio de Janeiro. 